Article

\title{
Low-Cost Organic Adsorbents for Elemental Mercury Removal from Lignite Flue Gas
}

\author{
Marta Marczak-Grzesik ${ }^{1,2, *}$, Stanisław Budzyń ${ }^{1}$, Barbara Tora ${ }^{3}$, Szymon Szufa ${ }^{4}{ }^{\oplus}$, Krzysztof Kogut $^{1}{ }^{1}$ and \\ Piotr Burmistrz ${ }^{1}$ \\ 1 Faculty of Energy and Fuels, AGH University of Science and Technology, Mickiewicz Avenue 30, \\ 30-059 Krakow, Poland; budzyn@agh.edu.pl (S.B.); kogut@agh.edu.pl (K.K.); burmistr@agh.edu.pl (P.B.) \\ 2 AGH Centre of Energy, AGH University of Science and Technology, Czarnowiejska 36, 30-054 Krakow, Poland \\ 3 Faculty of Mining and Geoengineering, AGH University of Science and Technology, Mickiewicz Avenue 30, \\ 30-059 Krakow, Poland; tora@agh.edu.pl \\ 4 Faculty of Process and Environmental Engineering, Lodz University of Technology, Wolczanska 213, \\ 90-924 Lodz, Poland; szymon.szufa@p.lodz.pl \\ * Correspondence: mmarczak@agh.edu.pl
}

Citation: Marczak-Grzesik, M.; Budzyń, S.; Tora, B.; Szufa, S.; Kogut, K.; Burmistrz, P. Low-Cost Organic Adsorbents for Elemental Mercury Removal from Lignite Flue Gas. Energies 2021, 14, 2174. https:// doi.org/10.3390/en14082174

Academic Editor: S.M.

Ashrafur Rahman

Received: 15 March 2021

Accepted: 11 April 2021

Published: 13 April 2021

Publisher's Note: MDPI stays neutral with regard to jurisdictional claims in published maps and institutional affiliations.

Copyright: (c) 2021 by the authors. Licensee MDPI, Basel, Switzerland. This article is an open access article distributed under the terms and conditions of the Creative Commons Attribution (CC BY) license (https:// creativecommons.org/licenses/by/ $4.0 /)$.

\begin{abstract}
The research presented by the authors in this paper focused on understanding the behavior of mercury during coal combustion and flue gas purification operations. The goal was to determine the flue gas temperature on the mercury emissions limits for the combustion of lignites in the energy sector. The authors examined the process of sorption of mercury from flue gases using fine-grained organic materials. The main objectives of this study were to recommend a low-cost organic adsorbent such as coke dust (CD), corn straw char (CS-400), brominated corn straw char (CS-400-Br), rubber char (RC-600) or granulated rubber char (GRC-600) to efficiently substitute expensive dust-sized activated carbon. The study covered combustion of lignite from a Polish field. The experiment was conducted at temperatures reflecting conditions inside a flue gas purification installation. One of the tested sorbents-tire-derived rubber char that was obtained by pyrolysis-exhibited good potential for $\mathrm{Hg}^{0}$ into $\mathrm{Hg}^{2+}$ oxidation, resulting in enhanced mercury removal from the flue. The char characterization increased elevated bromine content (mercury oxidizing agent) in comparison to the other selected adsorbents. This paper presents the results of laboratory tests of mercury sorption from the flue gases at temperatures of $95,125,155$ and $185^{\circ} \mathrm{C}$. The average mercury content in Polish lignite was $465 \mu \mathrm{g} \cdot \mathrm{kg}^{-1}$. The concentration of mercury in flue gases emitted into the atmosphere was $17.8 \mu \mathrm{g} \cdot \mathrm{m}^{-3}$. The study analyzed five low-cost sorbents with the average achieved efficiency of mercury removal from $18.3 \%$ to $96.1 \%$ for lignite combustion depending on the flue gas temperature.
\end{abstract}

Keywords: lignite; anthropogenic emission; mercury removal; flue gases purification; low-cost asorbents

\section{Introduction}

Ecotoxic elements, especially mercury, are particularly hazardous substances among pollutants with no physiological relevance for living organisms. It is generally known that mercury exposure can inflict various health issues, especially neurological, immunological, behavioral and sensory issues [1,2]. The mentioned afflictions were diagnosed in consumers of contaminated fish (Minamata Disease in Japan) and crops (Iraq, Guatemala and Russia). Mercury has an adverse impact on health, as well as long atmospheric lifetime and propensity for deposition in the aquatic environment and in living tissue. Due to the global distribution of mercury, the US Environmental Protection Agency [3] has classified it and its compounds as an air quality threat. Coal combustion release, which has constantly increased following growing worldwide energy demand, is considered as one of the most significant anthropogenic origins of mercury [3-5]. Therefore, due to the element's (wide) exposition, to avoid adverse harmful effects to the respiratory, nervous and immune systems, it is crucial to decrease atmospheric mercury emissions. Conducted research confirms 
the severe influence on the environment and warrants worldwide actions for the reduction of emissions [6-8].

In Poland, solid fuel combustion, mainly coal, constitutes the dominating source of mercury emission, exceeding $80 \%$ of the country's share $[9,10]$. Under the adoption of 2010/75/UE Directive (IED-Industrial Emissions Directive) that includes the permitted industrial emissions, the Polish energy sector has introduced the Best Available Technologies (BAT) methods with a permissible emission limit of $1-10 \mu \mathrm{g} \cdot \mathrm{Nm}^{-3}$, depending on the fuel used and plant size [10,11]. At present, the vast majority of units in Polish power plants do not meet the BAT-defined standards for mercury, which imposes the need for technological progress. As new emerging technologies such as clean coal technologies or deep desulfurization and denitrogenation do not meet the European standards for mercury emission, auxiliary means of mercury removal are needed to prevent power plant closures due to non-compliance with regulations. Among the techniques of standalone mercury removal systems, injection of powdered activated carbon (PAC) to flue gasses due to the high specific surface of the material is commonly utilized in the United States of America [12,13].

The efficiency of mercury removal using powdered sorbent injection depends on both physical and chemical properties of the material, flue gas temperature (inversely proportional, i.e. increases in temperature result in sorption decreases) and flue gas constituents (presence of halogen compounds and sulfur trioxide $\left(\mathrm{SO}_{3}\right)$ ). Furthermore, mercury speciation plays a vital role as the $\mathrm{Hg}^{2+}$ form of mercury has good affinity for sorbents capture, whereas $\mathrm{Hg}^{0}$ is practically not adsorbed. Therefore, oxidation of the mercury in order to increase the share of $\mathrm{Hg}^{2+}$ is an established practice [14-17].

The main disadvantage of activated carbon sorbent usage is the material price, which results in global research [18-21] aimed at the search for new low-cost adsorbents with comparable sorptive properties that can be used as a replacement (low-cost adsorbents). The authors suggest that the use of waste materials with no industrial application can be the most beneficial in both economic and environmental terms [22]. For example, Guangqian L. et al. [23] developed waste-derived sorbents from biomass and brominated flame retarded plastic for mercury removal from coal-fired flue gas. Charpenteau C. et al. [24] proposed coal fly ash as low-cost material. The authors of $[25,26]$ analyzed six low-cost sorbents with the average achieved efficiency of mercury removal of $30.6-92.9 \%$ for sub-bituminous coal and $22.8-80.3 \%$ for lignite combustion. One of the main objectives of this study was to recommend a low-cost organic sorbent such as coke dust to efficiently substitute expensive activated carbon for mercury removal from flue gas. Other researchers have attempted to develop alternative low-cost yet efficient adsorbents utilizing agricultural and industrial wastes [27-29]. Biochars play a significant role in addressing the current demands of adsorbents for various applications [30,31]. Initial research on specially prepared chars from rubber wastes has proven beneficial for the capture of both mercury [32] and other heavy metals [33]. Considering the amount of mercury released by the energy sector [34-40], the research was organized to determine the potential of rubber char as a sorbent for capturing mercury from flue gas at different temperatures and compare it to other possible adsorbents as an alternative for expensive activated carbons.

The purpose of this study was the application of dust-sized sorbents for reduction of mercury emissions from flue gas. The main objective of this study was to recommend a low-cost organic adsorbent such as coke dust (CD), corn straw char (CS-400), brominated corn straw char (CS-400-Br), rubber char (RC-600) or granulated rubber char (GRC-600) to efficiently substitute expensive dust-sized activated carbon. The study covered combustion of lignite from a Polish field. The experiment was conducted at temperatures reflecting conditions inside a flue gas purification installation. 


\section{Materials and Methods}

\subsection{Sorbents Origins}

To compare the efficiency of sorbents, studies consisted of five types of low-cost organic sorbents in three different forms: coke-derived char dust (CD), biomass chars (CS, $\mathrm{CS}-\mathrm{Br}$ ) and rubber-derived chars (RC and GRC). Commercially available activated carbon (AC) was included as industrial flue gas mercury sorbent of choice for comparative reasons. The sorbents used are described in Table 1.

Table 1. Description of low-cost organic adsorbent.

\begin{tabular}{|c|c|c|}
\hline LCOA & Sign & Description of Origin \\
\hline Activated carbon & $\mathrm{AC}$ & $\begin{array}{l}\text { Commercial activated carbon, dedicated, e.g., for gas-phase mercury removal. } \\
\text { It was formed in the process of coal carbonization and subsequent thermal } \\
\text { activation of the obtained structure. }\end{array}$ \\
\hline Coke dust & $\mathrm{CD}$ & $\begin{array}{l}\text { Byproduct of large-scale coke production. The dust is obtained during coke } \\
\text { dry-cooling process, hauling and sorting. }\end{array}$ \\
\hline Corn straw char & CS-400 & $\begin{array}{l}\text { Solid product (char) of corn straw torrefaction process using superheated } \\
\text { steam at } 400{ }^{\circ} \mathrm{C} .\end{array}$ \\
\hline $\begin{array}{l}\text { Brominated Corn } \\
\text { straw char }\end{array}$ & $\mathrm{CS}-400-\mathrm{Br}$ & $\begin{array}{l}\text { Solid product (char) of corn straw torrefaction process with the addition of } \\
\text { bromine; blend char/Br2 was prepared at ratio 5:1. }\end{array}$ \\
\hline Rubber Char & RC-600 & $\begin{array}{l}\text { Solid product (char) of car tire pyrolysis at } 600^{\circ} \mathrm{C} \text {. The material was derived } \\
\text { from industrial installations in which intact tires are subjected to high } \\
\text { temperatures. }\end{array}$ \\
\hline
\end{tabular}

LCOA, Low-Cost Organic Adsorbent.

\subsection{Sorbents Analysis}

The scope of the sorbent analysis listed in Section 2.1 includes:

(i) Proximate and ultimate analyses were performed in accordance with the ISO standard [41,42].

(ii) Determination of chlorine content was evaluated as chlorine anion content in water solution using a direct reading spectrophotometer (DR/2000 HACH). A sample was combusted in AC-350 bomb calorimeter (LECO) with Eschka mixture-in accordance with the ISO standard [43].

(iii) Mercury content was analyzed by thermal decomposition, amalgamation and atomic absorption spectrophotometry (DMA-80 Direct mercury analyser).

(iv) The particle size of LCOA was analyzed by ISO standard [44].

(v) The porous texture of all samples was analyzed using nitrogen adsorption-desorption at $77 \mathrm{~K}$ using Autosorb ${ }^{\circledR}-1-\mathrm{C}$ (Quantachrome Instruments, USA) according to the standards [45-48].

(vi) Bromine content was analyzed with X-ray spectrometry with wavelength dispersion in PROMUS II sequential spectrometer (Rigaku).

(vii) ED-XRF analyses of samples in a powder form were conducted with use of PANalytical EmpyreanXLE diffractometer with copper anode $(\mathrm{Cu} \mathrm{K} \alpha)$ in the $2 \theta$ angle range of $10-110^{\circ}$. The type and amount of crystalline phase were evaluated with PANalytical HighScore Plus software.

Values of these parameters were determined for the air-dried basis of the sample.

\subsection{Mercury Adsorption System}

The stand for measuring mercury sorption from flue gases generated by the combustion of solid fuels is shown in Figure 1. The bench-scale measurement setup consists of tube furnace (3) along with temperature and gas flow regulation with quartz tube (4) as the combustion chamber, gas source (1) and sorbent holder (8). The utilized equipment allows for controllable gas heating at specified points (9). The measurement procedure 
involves air-fueled coal sample (5) combustion and analysis of flue-gas mercury captured by the sorbent.

(6)

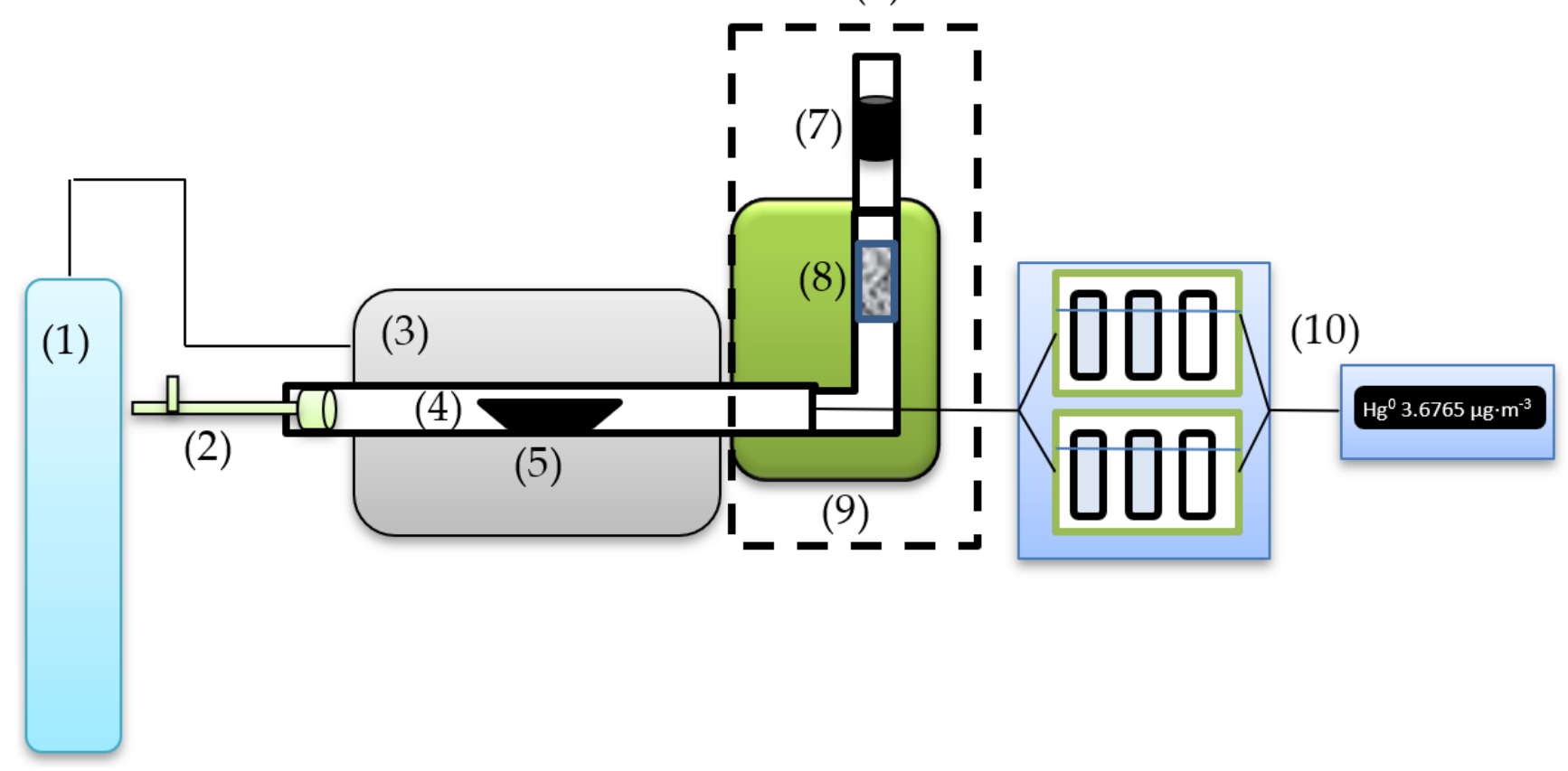

Figure 1. Test stand schematic: (1) gas source, air; (2) metal rod; (3) tube furnace; (4) quartz tube; (5) coal sample; (6) flue mercury adsorption device; (7) sorbent trap; (8) sorbent holder; (9) flue gases heating furnace; and (10) set of impingers with mercury survey meter EMP-3 of impingers for mercury speciation measurement.

The experiment was conducted with predetermined temperature conditions for sample combustion and sorbent temperature with similar combustion times and airflow. One gram of the sample was positioned in a ceramic boat-shaped crucible and progressively transported to the center of the combustion zone with a metal rod (2). The standardized measurement time after the crucible was introduced to the center of the combustion zone was $20 \mathrm{~min}$. Additionally, LCOA was placed a sorbent trap (7), which measured the concentration of $\mathrm{Hg}$ emitted into the atmosphere.

A more detailed description of the experimental conditions is presented in [25]. For the combustion process, lignite was used. It underwent ultimate and proximate analysis, with the additional steps of mercury and chlorine determination in accordance with the methodology described in Section 2.2.

The lignite sample was prepared in accordance with the ISO standards [49]. The characteristic of the used lignite is shown in Section 3.2.

\section{Mercury Speciation Testing}

To determine mercury speciation in flue gas samples, two sets of impingers (three impingers in each set) and a mercury survey meter EMP-3 (continuous mercury analyzer) were used. For the period of mercury speciation ascertainment, the flue mercury adsorption device (Figure 1, Point 6) was disengaged. Flue gases flowed by a series of impingers (Figure 1, Point 10). Raw flue gas was channeled into two flow streams. In the first vessel out of the first gas washing bottle setup, the $\mathrm{Hg}^{2+}$ mercury from the first stream was reduced to $\mathrm{Hg}^{0}$ with $10 \% \mathrm{SnCl}_{2}$ solution, followed by acidic gas scrubbing with $10 \% \mathrm{KOH}$ solution and subsequent moisture removal with the third vessel. The purified flue gas stream was then analyzed with an EMP-3 detector for total mercury content determination. The second gas washing bottle setup had an analogous configuration to the first setup, with the difference being the first vessel was used to capture $\mathrm{Hg}^{2+}$ mercury out of the second stream with $10 \% \mathrm{KCl}$ solution. Consequently, the EMP-3 detector analyzed the purified 
flue gas from the second stream for elementary mercury. The concentration of $\mathrm{Hg}^{2+}$ was determined based on the difference between total and elementary mercury.

\subsection{Methodology of Mercury Adsorption}

To check the reliability of the tests performed, the balance of mercury in the laboratory installation was calculated for each experiment in accordance with the following model:

$$
m_{c} \cdot C_{0}-m_{a s h} \cdot C_{a s h}=m_{\text {sorb }} \cdot\left(C_{H g}^{\prime \prime}-C_{H g}^{\prime}\right)+m_{\text {trap }} \cdot\left(C_{\text {trap }}^{\prime \prime}-C_{\text {trap }}^{\prime}\right)
$$

where $m_{c}$ is the mass of combusted coal $(\mathrm{kg}) ; C_{0}$ is the mercury content in coal $\left(\mu \mathrm{g} \cdot \mathrm{kg}^{-1}\right)$; $m_{a s h}$ is the mass of ash from coal combustion ( $\left.\mathrm{kg}\right) ; C_{a s h}$ is the $\mathrm{Hg}$ content in the ash $(\mathrm{kg}) ; m_{\text {sorb }}$ is the weight of tested sorbent $(\mathrm{kg}) ; \mathrm{C}_{\mathrm{Hg}}^{\prime}$ and $\mathrm{C}_{\mathrm{Hg}}^{\prime \prime}$ are the mercury concentrations in sorbent before and after sorption $\left(\mu \mathrm{g} \cdot \mathrm{kg}^{-1}\right) ; m_{\text {trap }}$ is the mass of sorbent trap [kg]; and $C_{\text {trap }}^{\prime}$ and $C_{\text {trap }}^{\prime \prime}$ are the mercury concentrations in the trap before and after the experiment $\left(\mu \mathrm{g} \cdot \mathrm{kg}^{-1}\right)$.

Based on the obtained data and measurements of flue gas mercury concentration before and after adsorption, the $\mathrm{Hg}$ adsorption capacities $\left(q, \mu \mathrm{g} \cdot \mathrm{g}^{-1}\right)$ of the sorbent samples were calculated using below equation:

$$
q=\frac{Q_{f g}}{m_{\text {sorb }}} \int_{0}^{t}\left(C_{f g}^{\prime \prime}-C_{f g}^{\prime}\right) d t
$$

where $Q_{f g}$ is the gas flow rate $\left(\mathrm{m}^{3} \cdot \mathrm{min}^{-1}\right)$ and $C_{f g}^{\prime \prime}$ and $C_{f g}^{\prime}$ are the inlet and outlet $\mathrm{Hg}$ concentrations in flue gases $\left(\mu \mathrm{g} \cdot \mathrm{Nm}^{-3}\right)$ at combustion time $\mathrm{t}(\mathrm{min})$.

Additionally, mercury removal efficiency of tested sorbents (MR, \%) was calculated as:

$$
M R=\frac{C_{H g}^{\prime \prime}-C_{H g}^{\prime}}{C_{0}-C_{a s h}} \cdot 100 \%
$$

\section{Results and Discussion}

\subsection{Sorbent Characteristics}

AC contained $6.1 \mu \mathrm{g} \mathrm{Hg} \cdot \mathrm{kg}^{-1}$ (Table 2). Relatively small quantities of mercury were also found in CD $\left(8.9 \mu \mathrm{g} \cdot \mathrm{kg}^{-1}\right)$ and CS-400 $\left(2.7 \mu \mathrm{g} \cdot \mathrm{kg}^{-1}\right) \mathrm{CD}$ and AC were obtained in the carbonization process, therefore they contained minimal quantities of volatiles: 3.2 $\mathrm{wt} \%$ for CD and $15 \%$ for AC. RC-600 and GRC-600 had high mercury content, at 158 and $73 \mu \mathrm{g} \cdot \mathrm{kg}^{-1}$, respectively, as well as ash $(19.8 \%$ and $19.6 \%$, respectively). Commercial activated carbon (AC) and rubber waste chars (RC-600 and GRC-600) recorded from 3.5 to 18 times higher sulfur content than other examined sorbents. Sorbents had bromine

\begin{tabular}{|c|c|c|c|c|c|c|c|c|c|}
\hline \multirow{2}{*}{ Sorbent } & \multicolumn{3}{|c|}{ Proximate Analysis (wt $\%$ ) } & \multicolumn{3}{|c|}{ Ultimate Analysis (wt $\%$ ) } & \multicolumn{2}{|c|}{$(w t \%)$} & \multirow{2}{*}{$\frac{\left(\mu \mathrm{g} \cdot \mathrm{kg}^{-1}\right)}{\mathrm{Hg}_{\mathrm{ad}}}$} \\
\hline & $\mathbf{M}_{\mathrm{ad}}$ & $\mathbf{V}_{\mathrm{ad}}$ & $\mathbf{A}_{\mathrm{ad}}$ & $\mathrm{C}_{\mathrm{ad}}$ & $\mathbf{H}_{\mathrm{ad}}$ & $\mathrm{S}_{\mathrm{ad}}$ & $\mathrm{Br}_{\mathrm{ad}}$ & $\mathrm{Cl}_{\mathrm{ad}}$ & \\
\hline $\mathrm{AC}$ & 9.2 & 15.09 & 26.2 & 59.5 & 1.45 & 2.11 & 0.017 & 0.021 & 6.1 \\
\hline $\mathrm{CD}$ & 0.4 & 3.19 & 9.8 & 85.0 & 0.16 & 0.59 & 0.014 & 0.023 & 8.9 \\
\hline CS-400 & 2.6 & 23.7 & 22.1 & 61.7 & 3.20 & 0.15 & 0.005 & 0.037 & 2.7 \\
\hline CS- $400-B r$ & - & - & - & - & - & - & 0.033 & - & 2.9 \\
\hline RC-600 & 1.3 & 3.2 & 19.8 & 75.4 & 0.91 & 2.55 & 0.068 & 0.063 & 158.1 \\
\hline GRC-600 & 2.3 & 3.2 & 19.6 & 76.3 & 0.95 & 2.66 & 0.073 & 0.075 & 73.0 \\
\hline
\end{tabular}
content in the range of 50-730 ppm.

Table 2. Properties of the analyzed sorbents.

$\mathrm{M}_{\mathrm{ad}}$, moisture in the air-dried basis; $\mathrm{V}_{\mathrm{ad}}$, volatile matter in the air-dried basis; $\mathrm{A}_{\mathrm{ad}}$, ash in an air-dried basis; $\mathrm{Cl}_{\mathrm{ad}}$ chlorine in the air-dried basis; $\mathrm{C}_{\mathrm{ad}}$, carbon in the air-dried basis; $\mathrm{H}_{\mathrm{ad}}$, hydrogen in the air-dried basis; $\mathrm{S}_{\mathrm{ad}}$, sulfur in the air-dried basis; $\mathrm{Br}_{\mathrm{ad}}$, bromine in the air-dried basis; $\mathrm{Hg}_{\mathrm{ad}}$, mercury in the air-dried basis.

Coke and rubber waste chars are microporous materials with a moderately developed mesoporous and poor microporous structure (Table 3). The specific surfaces $\left(\mathrm{S}_{\mathrm{BET}}\right)$ of $\mathrm{CD}$, 
RC-600 and GRC-600 have several dozen $\mathrm{m}^{2} \cdot \mathrm{g}^{-1}$, while in AC this parameter reaches $670.5 \mathrm{~m}^{2} \cdot \mathrm{g}^{-1}$. The specific surface area of corn straw char is $4.8 \mathrm{~m}^{2} \cdot \mathrm{g}^{-1}$. However, the mesoporous structure is an essential parameter for mercury adsorption because, due to the particle size of mercury, mesopores are considered to be dominant areas of its deposition. RC-600 and GRC-600 sorbents have the highest mesoporous surface among the analyzed samples: 0.38 and $0.17 \mathrm{~cm}^{3} \cdot \mathrm{g}^{-1}$, respectively. Therefore, these samples underwent further qualitative and quantitative phase analysis.

Table 3. Parameters of porous structure for LCOA.

\begin{tabular}{|c|c|c|c|c|}
\hline Sample & $\begin{array}{c}\text { BET Surface } \\
\text { Area }\left(\mathrm{m}^{2} \cdot \mathrm{g}^{-1}\right)\end{array}$ & $\begin{array}{c}\text { Micropore } \\
\text { Surface Area } \\
\left(\mathrm{cm}^{3} \cdot \mathrm{g}^{-1)}\right.\end{array}$ & $\begin{array}{c}\text { Mesopore } \\
\text { Volume } \\
\left(\mathrm{cm}^{3} \cdot \mathrm{g}^{-1}\right)\end{array}$ & $\begin{array}{l}\text { Total Pore } \\
\left(\mathrm{cm}^{3} \cdot \mathrm{g}^{-1}\right)\end{array}$ \\
\hline $\mathrm{AC}$ & 670.5 & 0.307 & 0.055 & - \\
\hline CD & 24.3 & 0.006 & 0.009 & 0.018 \\
\hline CS-400 & 4.8 & 0.001 & 0.010 & 0.023 \\
\hline CS-400-Br & 4.6 & 0.001 & 0.008 & 0.018 \\
\hline RC-600 & 70.3 & 0.025 & 0.380 & 0.396 \\
\hline GRC-600 & 74.7 & 0.023 & 0.171 & 0.239 \\
\hline
\end{tabular}

Qualitative and Quantitative Phase Analysis of Rubber Waste towards as a Sorbent

Based on conducted experimental studies presented in a previous publication [25], sorbents of rubber waste were the most promising material for flue gas mercury capture in lignite combustion processes. Therefore, only this material was selected for Scanning Electron Microscopy (SEM) using Energy Dispersive Spectroscopy (EDS system).

The results of the chemical analysis for selected RC-600 sample points (Figure 2) are shown in Table 4 . The char contains $78.5-80.8 \%$ carbon, most of which comes from carbon black used for tire production. Due to the point-based nature of the measurement, this amount does not correspond to the average content of carbon for the representative sample (Table 2). Another probable origin is tire pyrolytic oil that carbonized during rubber processing. The mineral content in the char is assumed to be a result of industry additives present in the tire manufacturing such as fillers, plasticizers, vulcanizing activators and crosslinking additives. The used matter consists of $\mathrm{SiO}_{2}, \mathrm{ZnO} \mathrm{CaO}, \mathrm{Al}_{2} \mathrm{O}_{3}, \mathrm{Na} 2 \mathrm{O}$ and $\mathrm{Fe}_{2} \mathrm{O}_{3}$ (Table 4).

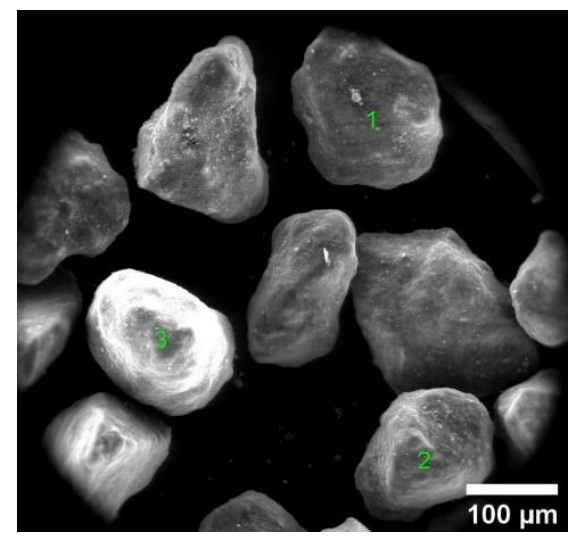

Figure 2. SEM image of RC-600. 
Table 4. Analysis EDS of selected points of RC-600.

\begin{tabular}{cccc}
\hline \multirow{2}{*}{ Element } & \multicolumn{3}{c}{ Chemical Components (wt) $)$} \\
\cline { 2 - 4 } & $\mathbf{1}$ & $\mathbf{2}$ & $\mathbf{3}$ \\
\hline $\mathrm{C}$ & 78.5 & 86.8 & 80.9 \\
$\mathrm{O}$ & 2.0 & 5.1 & 5.9 \\
$\mathrm{Mg}$ & 0.1 & 0.2 & 0.2 \\
$\mathrm{Al}$ & 0.2 & 0.2 & 0.3 \\
$\mathrm{Si}$ & 3.2 & 1.3 & 1.4 \\
$\mathrm{~S}$ & 4.7 & 2.2 & 2.0 \\
$\mathrm{Ca}$ & 1.2 & 0.2 & 4.8 \\
$\mathrm{Co}$ & 0.6 & 0.2 & 0.3 \\
$\mathrm{Cu}$ & 1.0 & 0.2 & 0.2 \\
$\mathrm{Zn}$ & 8.4 & 3.2 & 2.4 \\
\hline
\end{tabular}

Figure 3 shows example SEM images of the microstructure of RC-600 and GRC-600 chars. The picture presents small carbon particles aggregated into larger formations as the main constituent of the samples.

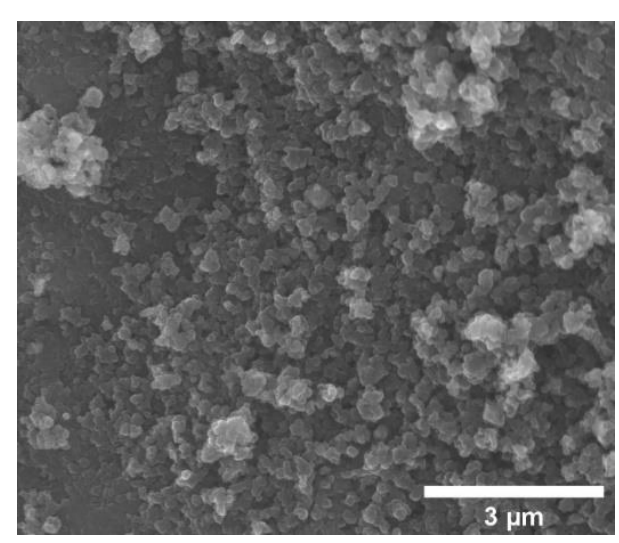

(a)

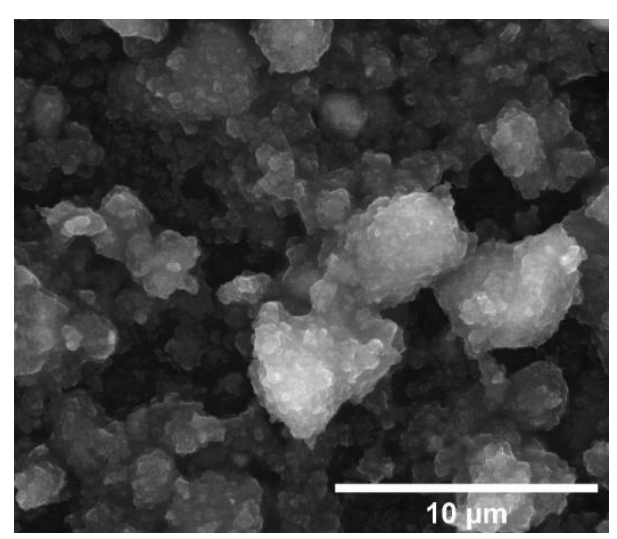

(b)

Figure 3. SEM images of: (a) RC-600; and (b) GRC-600.

\subsection{Properties of Lignite}

The characteristics of the combusted coal are shown in Table 5. Lignite contained an average of $465 \mu \mathrm{g} \cdot \mathrm{kg}^{-1}$ of mercury. The average content of halogens such as $\mathrm{Cl}$ and $\mathrm{Br}$ (supporting factors in the oxidation of mercury from $\mathrm{Hg}^{0}$ to $\mathrm{Hg}^{2+}$ ) in lignite was equal to $30 \mathrm{ppm} \mathrm{Cl}$ and $3.9 \mathrm{ppm} \mathrm{Br}$. The average sulfur content for the lignite was $1.8 \mathrm{wt} \%$; it also contained $23.7 \mathrm{wt} \%$ ash, $41.20 \mathrm{wt} \%$ volatiles and $12.9 \mathrm{wt} \%$ moisture.

Table 5. Characteristic of the coal used in the experiment.

\begin{tabular}{|c|c|c|c|c|c|c|c|c|c|c|}
\hline \multirow{2}{*}{ Coal } & \multicolumn{3}{|c|}{ Proximate Analysis (wt $\%)$} & \multicolumn{3}{|c|}{ Ultimate Analysis (wt\%) } & \multirow{2}{*}{$\frac{(w t \%)}{C a_{a d}}$} & \multicolumn{2}{|c|}{ (ppm) } & \multirow{2}{*}{$\frac{\left(\mu \mathrm{g} \cdot \mathrm{kg}^{-1}\right)}{\mathrm{Hg}_{\mathrm{ad}}}$} \\
\hline & $\mathbf{M}_{\mathrm{ad}}$ & $\mathrm{V}_{\mathrm{ad}}$ & $\mathbf{A}_{\mathrm{ad}}$ & $\mathrm{C}_{\mathrm{ad}}$ & $\mathrm{H}_{\mathrm{ad}}$ & $\mathrm{S}_{\mathrm{ad}}$ & & $\mathrm{Br}_{\mathrm{ad}}$ & $\mathrm{Cl}_{\mathrm{ad}}$ & \\
\hline Lignite & 12.9 & 41.20 & 23.7 & 43.5 & 4.90 & 1.80 & 2.42 & 3.9 & 30 & 465.0 \\
\hline
\end{tabular}

\subsection{Determination Mercury Speciation in Flue Gases during Lignite Combustion}

Figure 4 presents a Sankey diagram for mercury released from bench-scale lignite combustion with determination for various species of $\mathrm{Hg}$ at the flue gases temperature of $95^{\circ} \mathrm{C}$. Due to the experimental process, ash was a solid residue after coal combustion, and nearly all the mercury contained in the coal changed to the flue gas in gaseous forms $\left(\mathrm{Hg}^{0}\right.$ and $\left.\mathrm{Hg}^{2+}\right)$. Only $2 \%$ remained in the ashes in the $\mathrm{Hgp}$ form. The proportion of $\mathrm{Hg}^{0}$ in the analyzed flow was relatively high, reaching $70 \%$. The $\mathrm{Hg}^{0}: \mathrm{Hg}^{2+}$ ratio $(5: 2)$ was determined by the chemical composition of the fuel. Lignite is characterized by low content 
of chlorine and bromine (Table 5), which leads to oxidation of $\mathrm{Hg}^{0}$ to $\mathrm{Hg}^{2+}$. This effect, however, can be partially slowed down by relatively high presence of calcium $(2.42 \mathrm{wt} \%)$, which is capable of chemical deactivation of chlorine due to their chemical affinity [50]. The resulting fuel composition determines the share of $\mathrm{Hg}^{2+}$ to be $28 \%$ or lower. Due to behavioral differences between both forms, $\mathrm{Hg}^{0}$ is generally more difficult to remove from flue gas by the adsorption process. Therefore, the determining factor in the selection of sorbent and process conditions for mercury removal should be the chemical composition of the sorbents as well as the sorption temperature.
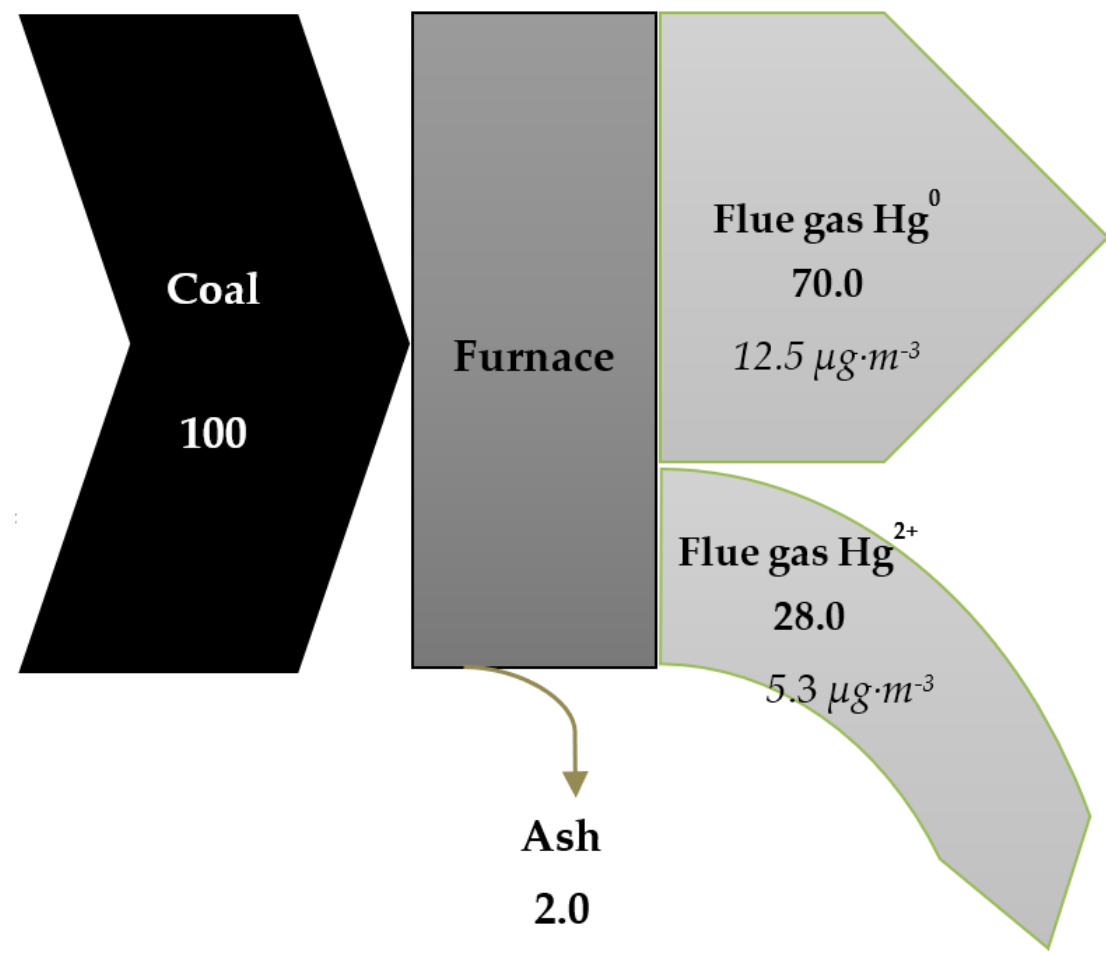

Figure 4. Sankey diagrams of mercury distribution (\%).

\subsection{Hg Adsorption Performance during Combustion of Lignite}

Table 6 shows the Hg adsorption capacity (q) of the tested sorbents and the efficiency of $\mathrm{Hg}$ removal from flue gas (MR) at process temperature of $95{ }^{\circ} \mathrm{C}$. The commercial activated carbon, currently used in active flue gas mercury removal methods, was the most efficient. AC removed the mercury almost entirely. The sorption efficiency of $\mathrm{CD}$ was also high at $93.8 \%$. RC-600 and GRC-600 presented mercury removal during combustion of lignite of $81.5 \%$ and $65.7 \%$, respectively. The analyses showed corn straw char to be the worst sorptive material during lignite combustion. CS-400 decreased the concentration of mercury in flue gas by only $32.4 \%$. CS- $400-\mathrm{Br}$ was more efficient in mercury removal (MR at $50 \%)$.

Table 6. Efficacy assessment of LCOA for $\mathrm{Hg}$ sorption.

\begin{tabular}{|c|c|c|}
\hline \multirow{2}{*}{ Sorbent } & $\mathbf{q}$ & MR \\
\hline & $\mu \mathrm{g} \cdot \mathrm{g}^{-1}$ & $\%$ \\
\hline $\mathrm{AC}$ & 102.6 & 96.1 \\
\hline CD & 100.2 & 93.8 \\
\hline CS-400 & 34.3 & 32.4 \\
\hline CS-400-Br & 53.4 & 50.1 \\
\hline RC-600 & 87.0 & 81.5 \\
\hline GRC-600 & 70.2 & 65.7 \\
\hline
\end{tabular}


As shown in Figure 5, the $\mathrm{Hg}$ concentration in raw flue gas was $17.8 \mu \mathrm{g} \cdot \mathrm{m}^{-3}$ (in the process of lignite combustion with a $\mathrm{Hg}$ content of $\left.465 \mu \mathrm{g} \cdot \mathrm{kg}^{-1}\right)$. Most of the mercury from flue gases was removed by AC and CD: their $\mathrm{Hg}$ adsorption capacities were 102.6 and $100.2 \mu \mathrm{g} \cdot \mathrm{g}^{-1}$, while the concentration of $\mathrm{Hg}$ in flue gases was decreased by 17.1 and $6.7 \mu \mathrm{g} \cdot \mathrm{m}^{-3}$, respectively, for AC and CD (Figure 5). Application of corn straw chars resulted in incomplete mercury removal. $\mathrm{Hg}$ adsorption capacity for CS-400 and CS-400-Br reached 34.3 and $53.4 \mu \mathrm{g} \cdot \mathrm{g}^{-1}$, respectively, which caused the reduction of mercury emission to 12.1 and $8.9 \mu \mathrm{g} \cdot \mathrm{m}^{-3}$. The low sorptive capability of CS-400 can be explained by its specific surface of $4.8 \mathrm{~m}^{2} \cdot \mathrm{g}^{-1}$. A higher value of $\mathrm{q}$ was obtained for rubber chars; the adsorption capacity was $87.0 \mu \mathrm{g} \cdot \mathrm{g}^{-1}$ for RC-600 and $70.2 \mu \mathrm{g} \cdot \mathrm{g}^{-1}$ for GRC-600. As a result, $\mathrm{Hg}$ concentration in flue gases was reduced to 3.3 and $6.1 \mu \mathrm{g} \cdot \mathrm{m}^{-3}$, respectively.

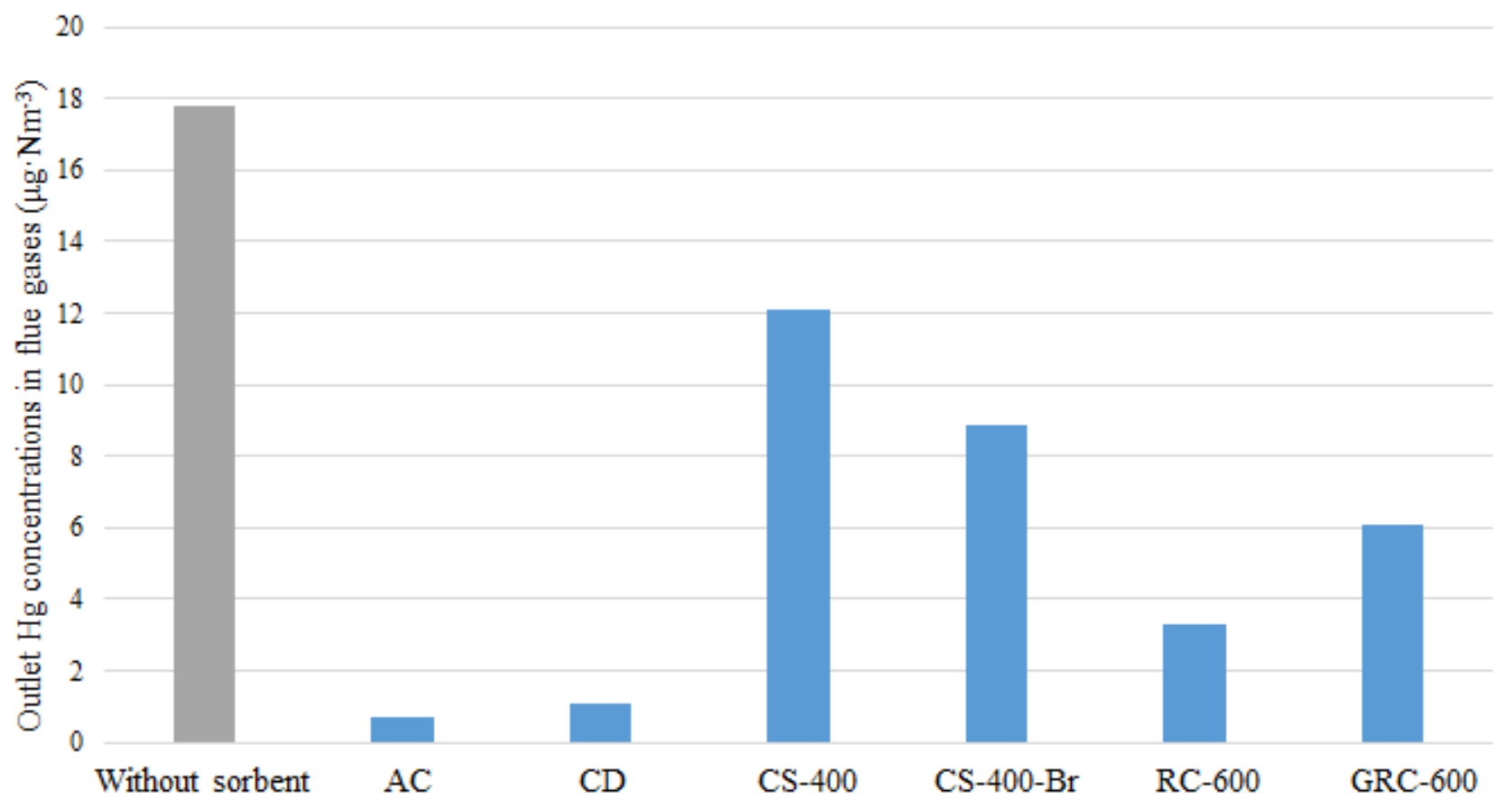

Type of sorbent

Figure 5. Concentration of mercury in raw flue gas and flue gases cleaned by LCOA.

\subsection{Effect of Flue Gas Temperature on Mercury Sorption Ability}

The next stage of the study considered the influence of the adsorption temperature on the effectiveness of LCOA in Hg removal. The average mercury removal effectiveness for $\mathrm{AC}, \mathrm{CD}$ and CS-400 decreased as the temperature increased, with the highest reading at $95^{\circ} \mathrm{C}$ and the lowest at $185^{\circ} \mathrm{C}$ (Table 7). The change in adsorption temperature had a different effect on RC-600, GRC-600 and CS-400-Br. The average mercury removal efficiency increased as the adsorption temperature increased, with the lowest results at $95{ }^{\circ} \mathrm{C}$ and the highest at $185^{\circ} \mathrm{C}$. 
Table 7. Efficacy assessment of LCOA for Hg sorption at different temperatures.

\begin{tabular}{cccc}
\hline \multirow{2}{*}{ Sorbent } & Temperature & $\mathbf{q}$ & $\mathbf{M R}$ \\
\cline { 2 - 4 } & ${ }^{\circ} \mathbf{C}$ & $\boldsymbol{\mu} \mathbf{g} \cdot \mathbf{g}^{-\mathbf{1}}$ & $\mathbf{\%}$ \\
\hline $\mathrm{AC}$ & 95 & 100.2 & 93.8 \\
$\mathrm{AC}$ & 125 & 95.4 & 89.3 \\
$\mathrm{AC}$ & 155 & 73.2 & 68.5 \\
$\mathrm{AC}$ & 185 & 72,0 & 67.4 \\
CD & 95 & 102,6 & 96.1 \\
CD & 125 & 94,2 & 88.2 \\
CD & 155 & 91,8 & 86.0 \\
CD & 185 & 84,0 & 78.7 \\
CS-400 & 95 & 34.3 & 32.1 \\
CS-400 & 125 & 29.4 & 27.5 \\
CS-400 & 155 & 24.2 & 22.7 \\
CS-400 & 185 & 19.5 & 18.3 \\
CS-400-Br & 95 & 53.4 & 50.1 \\
CS-400-Br & 125 & 55.2 & 51.7 \\
CS-400-Br & 155 & 58.8 & 55.1 \\
CS-400-Br & 185 & 61.2 & 57.3 \\
RC-600 & 95 & 87,0 & 81.5 \\
RC-600 & 125 & 93,6 & 87.6 \\
RC-600 & 155 & 99,0 & 92.7 \\
RC-600 & 185 & 101,7 & 95.2 \\
GRC-600 & 95 & 70,2 & 65.7 \\
GRC-600 & 125 & 84,0 & 78.7 \\
GRC-600 & 155 & 88,8 & 83.1 \\
GRC-600 & 185 & 97,2 & 91.0 \\
\hline
\end{tabular}

The average mercury concentration in flue gases during lignite combustion was $17.8 \mu \mathrm{g} \cdot \mathrm{m}^{-3}$ (Figure 6), whereas, after the adsorption process in the temperature range $\left(95-185{ }^{\circ} \mathrm{C}\right.$ ), the readings showed $1.1-5.8 \mu \mathrm{g} \cdot \mathrm{m}^{-3}$ for $\mathrm{AC}, 0.7-3.8 \mu \mathrm{g} \cdot \mathrm{m}^{-3}$ for CS and $12.1-14.6 \mu \mathrm{g} \cdot \mathrm{m}^{-3}$ for CS-400. CS-400 presented poor $\mathrm{Hg}$ removal performance at all tested temperatures, while the brominated CS-400-Br showed progression in $\mathrm{Hg}$ removal efficiency as temperature increased, similarly to RC-600 and GRC-600 (Figure 6).

The deciding factor for $\mathrm{Hg}$ removal efficiency can be the share of $\mathrm{Hg}^{0}$ in the flue. For AC, CD and CS-400, the Hg removal efficiency decreased with further increase in the adsorption temperature, whereas, for CS-400-Br, RC-600, GRC-600, the efficiency increased.

It was speculated that high adsorption temperature causes $\mathrm{Hg}$ desorption from the sorbent surface. However, the experiment showed that sorption temperature increase led to a higher share of $\mathrm{Hg}^{0}$ in the flue gas. The higher $\mathrm{Hg}$ removal of CS-400-Br, RC-600 and GRC-600 as the temperature raised can be connected to higher $\mathrm{Br}$ and $\mathrm{Cl}$ intrinsic content. 


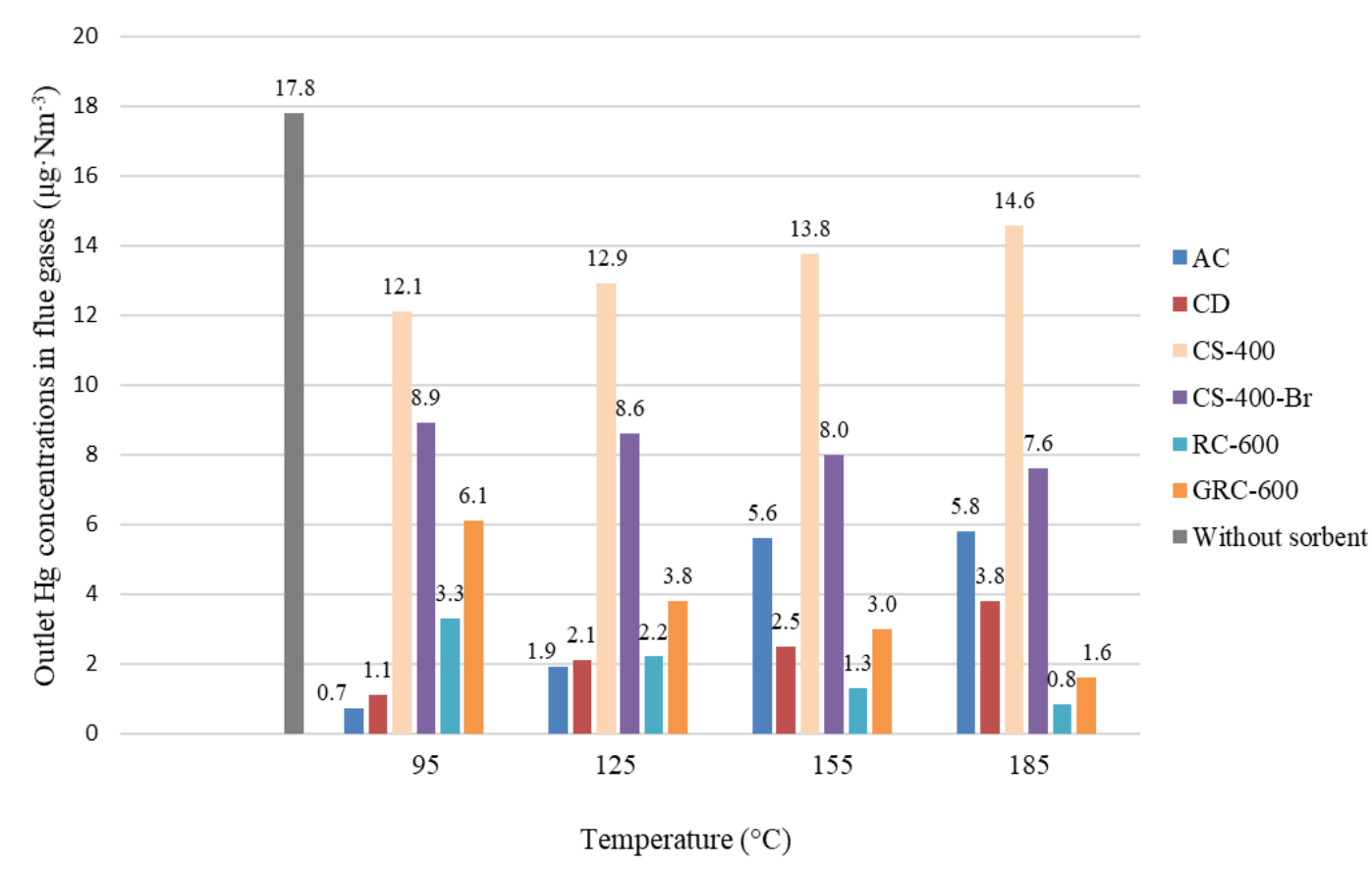

Figure 6. Concentration of mercury in raw flue gas and flue gases cleaned by LCOA depending on the temperature.

\section{Effect of Bromine Content in the Sorbent on $\mathrm{Hg}^{0}$ Oxidation}

Flue gases from lignite combustion are characterized by the high share of unoxidized $\mathrm{Hg}^{0}$ mercury. It is a volatile constituent of the flue with its ratio versus $\mathrm{Hg}^{2+}$ increasing with sorption temperature. $\mathrm{As}^{0} \mathrm{Hg}^{0}$ content increases, the average $\mathrm{Hg}$ removal efficiency for $\mathrm{AC}, \mathrm{CD}$ and $\mathrm{CS}$ was the highest for $95^{\circ} \mathrm{C}$ and the lowest for $185^{\circ} \mathrm{C}$.

AC, CD and CS-400 sorbency was determined by low bromine content, which resulted in lesser $\mathrm{Hg}^{2+}$ and therefore higher $\mathrm{Hg}^{0}$ amounts. The surface of the sorbent allows for $\mathrm{Hg}^{2+}$ adsorption, which can explain the pattern of higher sorptive properties of AC, CD and CS-400 at higher sorption temperatures, as the $\mathrm{Hg} 0$ content increases.

On the other hand, RC-600, GRC-600 and CS-400-Br were characterized by 2-14 times higher bromine content. Sorbent-present $\mathrm{Br}$ oxidized $\mathrm{Hg} 0$ in the flue to $\mathrm{Hg}^{2+}$ form at higher sorption temperatures, which obtained higher $\mathrm{Hg}^{2+}$ concentrations, along with higher removal capabilities [50]. The average $\mathrm{Hg}$ removal for RC-600, GRC-600 and CS400-Br followed the ascending order: $95^{\circ} \mathrm{C}<125^{\circ} \mathrm{C}<155^{\circ} \mathrm{C}<185{ }^{\circ} \mathrm{C}$. The proposed $\mathrm{Hg}^{0}$ oxidation and $\mathrm{Hg}^{2+}$ adsorption mechanism on RC-600, GRC-600 and CS-400-Br surfaces are presented in Figure $7 . \mathrm{Hg}^{0}$ was first oxidized at the activated site on the sorbent, followed by $\mathrm{Hg}^{2+}$ sorption. 


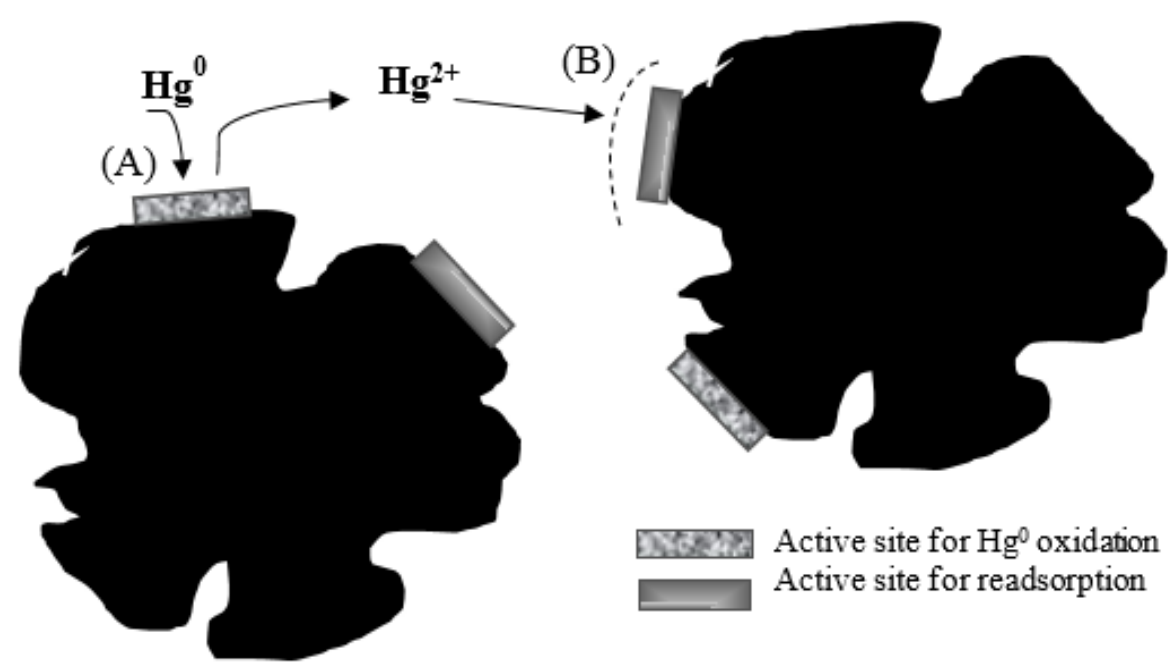

Suggested Hg removal mechanisms of Wa- 2 and Sa-4:

(A) $\mathrm{Hg}^{0}$ oxidation at the activated site.

(B) Readsorption of the resultant oxidized mercury at the site of RC-600/ GRC-600 available for adsorption.

Figure 7. Effect of bromine content in the sorbent on $\mathrm{Hg}^{0}$ oxidation.

To further assess the application prospect of such rubber waste-derived sorbents, a comparison of the accumulative $\mathrm{Hg}$ adsorption capacity of RC-600 and GRC-600 with other sorbents was conducted under similar experimental conditions (Figure 8). It demonstrated that longer sorption times (10-60 min, every $10 \mathrm{~min}$ ) led to increases in the accumulative properties for bromine-present sorbents. No time influence was observed for bromine-free (AC, CD and CS-400) sorbents.

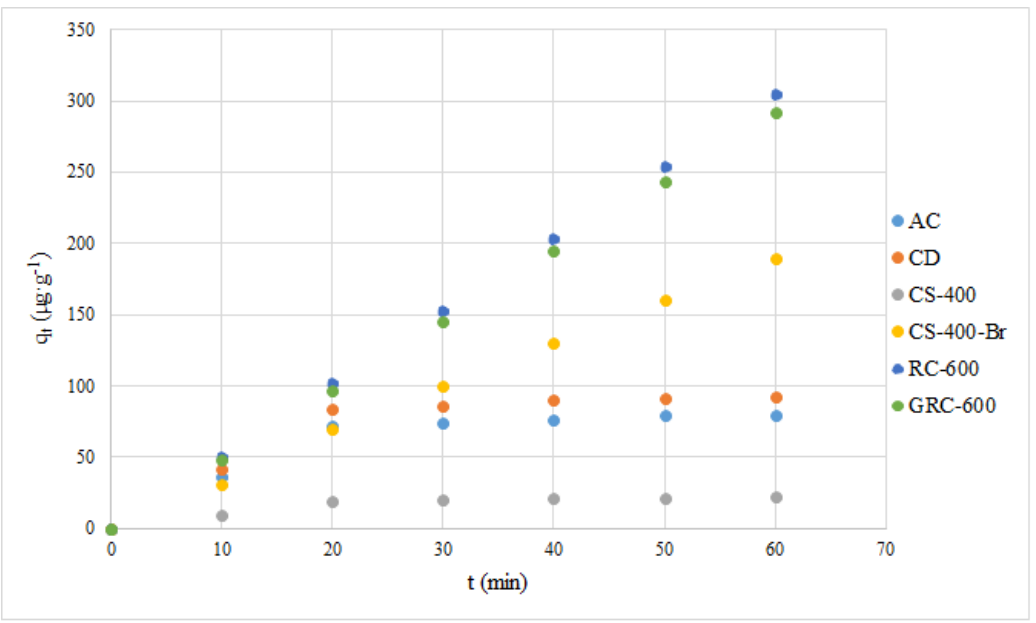

Figure 8. Accumulative $\mathrm{Hg}$ adsorption capacity for the tested sorbents.

\section{Conclusions}

This manuscript presents the results of mercury adsorption from lignite flue gas by the active method. For this purpose, we used six low-cost organic adsorbents (AC, CD, CS-400, CS-400-Br, RC-600 and GRC-600). The presented results allow drawing the following conclusions: the efficiency of sorbents for removal of mercury from flue gases at $95{ }^{\circ} \mathrm{C}$ decreased successively: AC (96.1\%) and CD (93.8\%), followed by RC-600 (81.5\%) and GRC-600 (65.7\%). The CS-400-Br exhibited better Hg removal performance compared to virgin biochar CS-400. The doping of sorbents with bromine resulted in a higher share of $\mathrm{Hg} 0$ oxidation to $\mathrm{Hg}^{2+}$ species. Low mercury removal efficiency by CS-400 was caused by its low mesopore volume $\left(0.01 \mathrm{~cm}^{3} \cdot \mathrm{g}^{-1}\right)$. The $\mathrm{Hg}$ removal efficiency for $\mathrm{AC}, \mathrm{CD}$ and 
biochars (CS-400) decreased with the increase of temperature, caused by a higher amount of sorption inactive $\mathrm{Hg}^{0}$ mercury in the flue gas.

CS-400-Br, RC-600 and GRC-600 enhanced their mercury adsorption capacity with an increase in the temperature. These sorbents had a higher bromine content (2-14 times) than other sorbents. Therefore, it can be confirmed that bromine had positive effects on $\mathrm{Hg}^{0}$ removal due to its influence on better $\mathrm{Hg}^{0}$ oxidation as well as adsorption on the free sites of the surface. In this study, a novel sorbent was created with one-step pyrolysis of tire waste for $\mathrm{Hg}^{0}$ removal from lignite flue gas. This method could combine municipal solid waste disposal and mercury sorbent preparation in one process. The $\mathrm{Hg}$ adsorption capacities of RC-600 and GRC-600 were close to those of commercial activated carbons.

Author Contributions: Conceptualization, M.M.-G. and S.B.; methodology, S.B. and M.M.-G.; validation, K.K.; formal analysis, S.B. and M.M.-G.; investigation, S.B. and M.M.-G.; resources, S.B., M.M.-G. and S.S.; data curation, M.M.-G.; writing—original draft preparation, M.M.-G.; writing-review and editing, M.M.-G., S.B., P.B., B.T. and S.S.; visualization, M.M.-G.; and funding acquisition, M.M.-G. and S.B. All authors have read and agreed to the published version of the manuscript.

Funding: This work was co-financed from the Research Subsidy of the AGH University of Science and Technology for the Faculty of Energy and Fuels (No. 16.16.210.476) and by the National Centre for Research and Development (NCRD) Poland within the LIDER X edition research program. The research and development project is entitled "Prediction of $\mathrm{Hg}$ and As distribution during the process of subbituminous and lignite coals combustion in pulverised coal-fired boiler and its flue gas cleanup with use of regression models and neural networks" (grant No. LIDER/33/0183/L-10/18/NCBR/2019). This work was supported by research infrastructure of the AGH Center of Energy.

Institutional Review Board Statement: Not applicable.

Informed Consent Statement: Not applicable.

Data Availability Statement: Not applicable.

Conflicts of Interest: The authors declare no conflict of interest.

\section{References}

1. Sloane, E.; Ledeboer, A.; Seibert, W.; Coats, B.; Van Strien, M.; Maier, S.F.; Johnson, K.; Chavez, R.; Watkins, L.; Leinwand, L.; et al. Anti-inflammatory cytokine gene therapy decreases sensory and motor dysfunction in experimental Multiple Sclerosis: MOG-EAE behavioral and anatomical symptom treatment with cytokine gene therapy. Brain Behav. Immun. 2009, 23, 92-100. [CrossRef]

2. Rice, K.M.; Walker, E.M.; Wu, M.; Gillette, C.; Blough, E.R. Environmental Mercury and Its Toxic Effects. J. Prev. Med. Public Health 2014, 47, 74-83. [CrossRef]

3. U.S. Environmental Protection Agency Office of Air Quality Planning and Standards Air Quality Assessment Division. National Air Quality. Status and Trends through 2007, North. Carolina. 2008. Available online: https://www.epa.gov/sites/production/ files /2017-11/documents/trends_brochure_2007.pdf. (accessed on 31 March 2021).

4. Wang, Z.; Liu, J.; Zhang, B.; Yang, Y.; Zhang, Z.; Miao, S. Mechanism of Heterogeneous Mercury Oxidation by HBr over $\mathrm{V}_{2} \mathrm{O}_{5} / \mathrm{TiO}_{2}$ Catalyst. Environ. Sci. Technol. 2016, 50, 5398-5404. [CrossRef]

5. Xu, Y.; Ding, H.; Luo, C.; Zheng, Y.; Xu, Y.; Li, X.; Zhang, Z.; Shen, C.; Zhang, L. Effect of lignin, cellulose and hemicellulose on calcium looping behavior of CaO-based sorbents derived from extrusion-spherization method. Chem. Eng. J. 2018, 334, 2520-2529. [CrossRef]

6. Yang, W.; Liu, Y.; Wang, Q.; Pan, J. Removal of elemental mercury from flue gas using wheat straw chars modified by Mn-Ce mixed oxides with ultrasonic-assisted impregnation. Chem. Eng. J. 2017, 326, 169-181. [CrossRef]

7. Ren, W.; Duan, L.; Zhu, Z.; Du, W.; An, Z.; Xu, L.; Zhang, C.; Zhuo, Y.; Chen, C. Mercury Transformation and Distribution Across a Polyvinyl Chloride (PVC) Production Line in China. Environ. Sci. Technol. 2014, 48, 2321-2327. [CrossRef] [PubMed]

8. Zhang, B.; Zeng, X.; Xu, P.; Chen, J.; Xu, Y.; Luo, G.; Xu, M.; Yao, H. Using the Novel Method of Nonthermal Plasma To Add Cl Active Sites on Activated Carbon for Removal of Mercury from Flue Gas. Environ. Sci. Technol. 2016, 50, 11837-11843. [CrossRef]

9. Li, H.; Zhu, L.; Wang, J.; Li, L.; Shih, K. Development of Nano-Sulfide Sorbent for Efficient Removal of Elemental Mercury from Coal Combustion Fuel Gas. Environ. Sci. Technol. 2016, 50, 9551-9557. [CrossRef] [PubMed]

10. European Union Emission Inventory Report 1990-2018 under the UNECE Convention on Long-Range Transboundary Air Pollution (LRTAP), Heavy Metal. Emissions, EEA Report No 05/2020. Available online: https:/ / www.eea.europa.eu/publications / european-union-emission-inventory-report-1990-2018 (accessed on 31 March 2021). 
11. Guidance on Best Available Techniques and Best Environmental Practices to Control Mercury Emissions from Coal-fired Power Plants and Coal-fired Industrial Boilers. Available online: https:/ / pdfs.semanticscholar.org/c145/fdc24793cfc6bb6149659597533 a585a4b8f.pdf?_ga=2.183433376.761095129.1552896150-1368528823.1551788871 (accessed on 7 December 2020).

12. European Commission. Best Available Techniques (BAT) Conclusions Scope, Ref. Ares 1248230-09/03/2017. Available online: https:/ / eur-lex.europa.eu/legal-content/EN/TXT/PDF/?uri=CELEX:32017D1442\&from=en (accessed on 31 March 2021).

13. Galbreath, K.C.; Zygarlicke, C.J. Mercury transformations in coal combustion flue gas. Fuel Process. Technol. 2000, 65-66, 289-310. [CrossRef]

14. Favale, A.; Nakamoto, T.; Kato, Y.; Nagai, Y. Mercury Mitigation Strategy through the Co-Beneift Of Mercury Oxidation with SCR Catalyst. Available online: http://www.mercuryconvention.org/Portals/11/documents/meetings/EG1/Catalyst_HCR.PDF (accessed on 31 March 2021).

15. Liu, Y.; Zhang, J.; Yin, Y. Study on absorption of elemental mercury from flue gas by UV/H2O2: Process parameters and reaction mechanism. Chem. Eng. J. 2014, 249, 72-78. [CrossRef]

16. Srivastava, R.K.; Hutson, N.; Martin, B.; Princiotta, F.; Staudt, J. Control of Mercury Emissions from Coal-Fired Electric Utility Boilers. Environ. Sci. Technol. 2006, 40, 1385-1393. [CrossRef]

17. Olson, E.S.; Azenkeng, A.; Laumb, J.D.; Jensen, R.R.; Benson, S.A.; Hoffmann, M.R. New developments in the theory and modeling of mercury oxidation and binding on activated carbons in flue gas. Fuel Process. Technol. 2009, 90, 1360-1363. [CrossRef]

18. Zhang, J.; Duan, Y.; Zhou, Q.; Zhu, C.; She, M.; Ding, W. Adsorptive removal of gas-phase mercury by oxygen non-thermal plasma modified activated carbon. Chem. Eng. J. 2016, 294, 281-289. [CrossRef]

19. Zhao, S.; Duan, Y.; Li, C.; Li, Y.; Chen, C.; Liu, M.; Lu, J. Partitioning and Emission of Hazardous Trace Elements in a 100 MW Coal-Fired Power Plant Equipped with Selective Catalytic Reduction, Electrostatic Precipitator, and Wet Flue Gas Desulfurization. Energy Fuels 2017, 31, 12383-12389. [CrossRef]

20. Charpenteau, C.; Seneviratne, R.; George, A.; Millan, M.; Dugwell, D.R.; Kandiyoti, R. Screening of Low Cost Sorbents for Arsenic and Mercury Capture in Gasification Systems. Energy Fuels 2007, 21, 2746-2750. [CrossRef]

21. Seneviratne, H.R.; Charpenteau, C.; George, A.; Millan, M.; Dugwell, D.R.; Kandiyoti, R. Ranking Low Cost Sorbents for Mercury Capture from Simulated Flue Gases. Energy Fuels 2007, 21, 3249-3258. [CrossRef]

22. Liu, Z.; Yang, W.; Xu, W.; Liu, Y. Removal of elemental mercury by bio-chars derived from seaweed impregnated with potassium iodine. Chem. Eng. J. 2018, 339, 468-478. [CrossRef]

23. Fuente-Cuesta, A.; Lopez-Anton, M.; Diaz-Somoano, M.; Martínez-Tarazona, M. Retention of mercury by low-cost sorbents: Influence of flue gas composition and fly ash occurrence. Chem. Eng. J. 2012, 213, 16-21. [CrossRef]

24. Xu, Y.; Deng, F.; Pang, Q.; He, S.; Xu, Y.; Luo, G.; Yao, H. Development of waste-derived sorbents from biomass and brominated flame retarded plastic for elemental mercury removal from coal-fired flue gas. Chem. Eng. J. 2018, 350, 911-919. [CrossRef]

25. Marczak, M.; Budzyń, S.; Szczurowski, J.; Kogut, K.; Burmistrz, P. Active methods of mercury removal from flue gases. Environ. Sci. Pollut. Res. 2018, 26, 8383-8392. [CrossRef]

26. Burmistrz, P.; Czepirski, L.; Kogut, K.; Strugała, A. Removing mercury from flue gases: A demo plant based on injecting dusty sorbents. Chem. Ind. (Przemyst Chem.) 2014, 93, 2014-2019. [CrossRef]

27. Tareq, R.; Akter, N.; Azam, S. Chapter 10-Biochars and Biochar Composites: Low-Cost Adsorbents for Environmental Remediation, Biochar from Biomass and Waste; Elsevier Inc.: Amsterdam, The Netherlands, 2019; pp. 169-209. [CrossRef]

28. Szufa, S. Use of superheated steam in the process of biomass torrefaction. Przem. Chem. 2020, 99, 1797-1801. (In Polish)

29. Szufa, S.; Piersa, P.; Adrian, Ł.; Sielski, J.; Grzesik, M.; Romanowska-Duda, Z.; Piotrowski, K.; Lewandowska, W. Acquisition of Torrefied Biomass from Jerusalem Artichoke Grown in a Closed Circular System Using Biogas Plant Waste. Molecules 2020, 25, 3862. [CrossRef] [PubMed]

30. Szufa, S.; Wielgosiński, G.; Piersa, P.; Czerwińska, J.; Dzikuć, M.; Adrian, Ł.; Lewandowska, W.; Marczak, M. Torrefaction of Straw from Oats and Maize for Use as a Fuel and Additive to Organic Fertilizers-TGA Analysis, Kinetics as Products for Agricultural Purposes. Energies 2020, 13, 2064. [CrossRef]

31. Szufa, S.; Piersa, P.; Adrian, Ł.; Czerwińska, J.; Lewandowski, A.; Lewandowska, W.; Sielski, J.; Dzikuć, M.; Wróbel, M.; Jewiarz, M.; et al. Sustainable Drying and Torrefaction Processes of Miscanthus for Use as a Pelletized Solid Biofuel and Biocarbon-Carrier for Fertilizers. Molecules 2021, 26, 1014. [CrossRef]

32. Li, G.; Shen, B.; Lu, F. The mechanism of sulfur component in pyrolyzed char from waste tire on the elemental mercury removal. Chem. Eng. J. 2015, 273, 446-454. [CrossRef]

33. Chan, O.S.; Cheung, W.H.; Ckay, G.M. Equilibrium and Kinetics of Lead Adsorption onto Tyre Char. HKIE Trans. 2012, 19, 20-28. [CrossRef]

34. Selbes, M.; Yilmaz, O.; Khan, A.A.; Karanfil, T. Leaching of DOC, DN, and inorganic constituents from scrap tires. Chemosphere 2015, 139, 617-623. [CrossRef]

35. Martínez, J.D.; Puy, N.; Murillo, R.; García, T.; Navarro, M.V.; Mastral, A.M. Waste tyre pyrolysis-A review. Renew. Sustain. Energy Rev. 2013, 23, 179-213. [CrossRef]

36. Manirajah, K.; Sukumaran, S.V.; Abdullah, N.; Razak, H.A.; Ainirazali, N. Evaluation of Low Cost-Activated Carbon Produced from Waste Tyres Pyrolysis for Removal of 2-Chlorophenol. Bull. Chem. React. Eng. Catal. 2019, 14, 443-449. [CrossRef]

37. Dimpe, K.M.; Ngila, J.C.; Nomngongo, P.N. Application of waste tyre-based activated carbon for the removal of heavy metals in wastewater. Cogent Eng. 2017, 4, 1-11. [CrossRef] 
38. Styszko, K.; Baran, P.; Sekuła, M.; Zarębska, K. Sorption of pharmaceuticals residues from water to char (scrap tires) impregnated with amines. E3S Web Conf. 2017, 14, 2029. [CrossRef]

39. Gupta, V.; Gupta, B.; Rastogi, A.; Agarwal, S.; Nayak, A. Pesticides removal from waste water by activated carbon prepared from waste rubber tire. Water Res. 2011, 45, 4047-4055. [CrossRef] [PubMed]

40. Global Mercury Assessment. Sources, Emissions, Releases and Environmental Transport; United Nations Environment Programme: Geneva, Switzerland, 2018.

41. ISO/TC 27/SC 5. ISO 17246:2010, Coal-Proximate Analysis; International Organization for Standardization (ISO): Geneva, Switzerland, June 2010.

42. ISO/TC 27/SC 5. ISO 17247:2013, Coal-Ultimate Analysis; International Organization for Standardization (ISO): Geneva, Switzerland, July 2013.

43. ISO/TC 27/SC 5. ISO 587:2020, Solid Mineral Fuels—Determination of Chlorine Using Eschka Mixture; International Organization for Standardization (ISO): Geneva, Switzerland, August 2020.

44. ISO/TC 27/SC 3. ISO 728:1995—Coke (Nominal Top Size Greater than 20 mm)—Size Analysis by Sieving; International Organization for Standardization (ISO): Geneva, Switzerland, November 1995.

45. Klobes, P.; Munro, R. Porosity and Specific Surface Area Measurements for Solid Materials; National Institute of Standards and Technology: Gaithersburg, MD, USA, 2006. Available online: https://tsapps.nist.gov/publication/get_pdf.cfm?pub_id=854263 (accessed on 13 April 2021).

46. ISO/TC 24/SC 4. ISO 9277: 2010—Determination of the Specific Surface Area of Solids by Gas Adsorption-BET Method; International Organization for Standardization (ISO): Geneva, Switzerland, September 2010.

47. ISO/TC 24/SC 4. ISO 15901-2: 2006-Pore Size Distribution and Porosity of Solid Materials by Mercury Porosimetry and Gas AdsorptionPart. 2: Analysis of Mesopores and Macropores by Gas Adsorption; International Organization for Standardization (ISO): Geneva, Switzerland, December 2006.

48. ISO/TC 24/SC 4. ISO 15901-3: 2007-Pore Size Distribution and Porosity of Solid Materials by Mercury Porosimetry and Gas AdsorptionPart. 3: Analysis of Micropores by Gas Adsorption; International Organization for Standardization (ISO): Geneva, Switzerland, April 2007.

49. ISO/TC 24/SC 4. ISO 5069-2: 1983 Brown Coals and Lignites-Part 2: Sample Preparation for Determination of Moisture Content and for General Analysis; International Organization for Standardization (ISO): Geneva, Switzerland, December 1983.

50. Zhang, L.; Zhuo, Y.; Chen, L.; Xu, X.; Chen, C. Mercury emissions from six coal-fired power plants in China. Fuel Process. Technol. 2008, 89, 1033-1040. [CrossRef] 